\title{
An Investigation on the Creation and Existence of Yuefu Lyric Poetry of the Xianbei Regime during the Northern and Southern Dynasties*
}

\author{
Xing Tang \\ School of Liberal Arts \\ Northwest Minzu University \\ Lanzhou, China
}

\begin{abstract}
During the period of the Northern and Southern Dynasties, the regimes of northern ethnic minority were everywhere. After the Xianbei nationality began to rise in the northeast, they turned to fight in the east and the west, and established a number of independent regimes. They almost crossed the entire period of the Northern Dynasties. With the establishment of these Xianbei ethnic regimes, the Yuefu lyric poetry has both inherited and newly created in various political powers. It shows differences and uniqueness in the subject matter, content, quantity, and ethnic composition of the author. And at the same time, it presents a certain degree of commonality and succession.
\end{abstract}

Keywords-Southern and Northern Dynasties; Xianbei regime; Yuefu lyric poetry; creation; existence

\section{INTRODUCTION}

During the Northern and Southern Dynasties, the northern multi-nationals co-existed, thoughts were mixed, the attack continued, and the regime flourished. At that time, the Murong, Qifu, Tufa, Tuoba, and Yuwen of Xianbei nationality all rose one after another, and they established power. Murongwei established former Yan. Muronghong established Xiyan. Murongchui established Post-Yan. Murongde established South Yan. Tufa Wugu established South Liang. Qifu Guoren established West Qin. Tuoba Gui established Northern Wei. Yuwen Tai established Western Wei and North Zhou. Gao Huan, Xianbei Chinese Han people, established the Eastern Wei and Northern Qi.

The Yuefu lyric poetry is an important literary and artistic form during the Northern and Southern Dynasties. In particular, the Yuefu lyric poetry of North Dynasty took root in the Northland soil. It has inherited Yuefu lyric poetry of the Han and Wei Dynasties. It also has inherited Wusheng Xiqu and Yuefu lyric poetry of the Southern Dynasty. And then, it has formed a unique style. It has different degrees of influence on other literary styles of the Northern and Southern Dynasties and poetry of Sui and Tang Dynasty, and the poetry of Song and Yuan Dynasties, Tang dynasty and

*Fund Project: Fundamental Research Funding for Central colleges of Northwest Minzu University for Postgraduate Project "The research on the creation of Yuefu lyric poetry of Northern Zhou Dynasty in the dimension of rites and music" (Project Number: Yxm2017002)
Five Dynasties. Scholars paid much attention to Yuefu lyric poetry of the Northern Dynasties. However, the focus of research has been on individual articles and important writers for a long time. In recent years, this situation has been improved. However, there are still many problems that need further investigation.

\section{CREATION AND EXISTENCE OF YUEFU LYRIC POETRY DURING FOEMER YAN TO NORTHERN WEI DYNASTY}

The Yuefu lyric poetry created under Xianbei regime of South and North Dynasties should be "Agan Song" in Foemer Yan established by Murongwei. In "Jin Shu", "Xianbei called the brother Agan, and Murongwei recalled it with a song of Agan"[1]. (Vol. 97, "Siyi-Xirong-Tuyuhun Biography"). Cao Daoheng believed that this song was created at the beginning of Murongwei's throne. [2] Since then, many Xianbei regimes have established their own Yuefu institutions [3] to collect and manage folk music houses, and to process and create Yuefu lyric poetry. According to Guo Maoqian's "The Yuefu Poem Collection", "the Melody of Liang Dynasty includes thirty-six songs such as Qiyu, the king of Yinli, Julu princess, Zixuanma, Huang Dansi, Diqule, Quelaoli, Murongchui, the water flow of Longtou. Twenty-five poems have songs and sounds, and eleven poems have songs. At that time, the Yuefu blowed old poems including Dabaijing prince, Xiaobaijing prince, Yongtai, kantai, Hu Zun, Li Qiuqiu, Chunyu Wang, Zhuo Yu, Dong Ping Liu Sheng, Dan Dili, Lu Shuang, Half-Qiyu, Bidun, $\mathrm{Hu} \mathrm{Du}$ and other fourteen songs. Three poems have songs, and eleven poems died. There are Gegu, Diqule, Zixuanma, Zheyangliu, the Youzhou Makeyin, the Murong Luqi, Longtou, Wei Gaoyang Wang and other twenty-seven songs. There are three pre-combination songs, and thirty fan songs. The total is 66 songs. [4] Of these 66 songs, there are at least four songs of "Qi Yu", eight songs of "Kings of Langya", three songs of "Julu Princess Song", and two songs of "Zixuan Ma", three songs of "Murongchui Song", 4 songs of "breaking willow", 5 songs of "Youzhou driver", 1 song of "Murong Luqi", 3 songs of "Longtou" [5]. The total is 33 songs.

Among them, the three songs of "Qiyu" can be found in the Xianbei regime. According to "Old Tang Dynasty- 
Music Book", "the music of Northern Di is known by Xianbei, Tuyuhun, and the tribe of Ji. All are happy immediately.... Zhou, Sui and Western Liang only have fiftythree chapters left today. The solvable six chapters include Murong Khan, Tuyuhun, Tribe Ji, Princess Julu, Prince Baijing, and Qiyu. Also, they would call "Khan"... According to North Korea's customs, they would call the Lord "Khan". Tu Yuhun and Murong have different kinds of species. They know that this song is the Xianbei song during Yan and Wei dynasties. [6] There are 3 songs of "Mongrong Chuige". In "the book of Jinshu", "Murongjun was Chuiwei". In Gao Renxiong's "Northern national literature narration", "Murong" refers to Murong Yong. "Wu Jun" refers to the army of Murongchui. The whole speech eulogized Murongchui defeating and destroying West Yan [7]. There is 1 song of "Murong Luqi". From the lyric poetry, it is also known as Xianbei songs.

Due to the "Gujin Yuelu", there were a total of 66 songs collected from the Melody of Liang Dynasty and Yuefu songs. In addition to the 33 songs in the Sixteen Kingdoms period, there are still 33 songs, including four songs of "Zixuanma". In "Gujin Yuelu", there is saying that fifteenyear-old boy should go to the army. And it is an ancient poem. People used Northern songs to piece together and process them, removing them. Then, there are 29 songs, which can be roughly considered to be created in the Northern Wei Dynasty. During the period, many songs have been transformed.

The Northern Wei Dynasty unifies the north. And the original 16-nation Yuefu is integrated into the Yuefu lyric poetry of northern Wei Dynasty. "Weishu Yuezhi" contains the end of the Northern Wei Dynasty. There are 500 Yuefu songs [10]. In "The Old Tang Dynasty-Music Book", there are many songs of North Di dynasty, Zhou dynasty, Sui dynasty and West Liang dynasty. There are fifty-three songs in the world. And there are six solvable songs. They include Murong Khan, Tuyuhun, tribal ji, Julu princess, Bai Jing prince and Qi Yu. Also, they would call "Khan"... They know that this song is Xianbei song during Yan and Wei dynasties. After "The Yuefu Poem Collection" in the Wei Dynasty, there is "Boluo Huige". There is "Khan" in the song. All are Xianbei songs during Yan and Wei dynasties. "Weishu Yuezhi" includes "real people"... It is a total of 150 songs. "Old Tang dynasty-Music Book" has North songs in Wei dynasty. That is the so-called "human songs". In addition, "The Yuefu Collection" contains 20 songs of Yuefu in Northern Wei dynasty. It includes Gao Yun's "Prince Joe" and "Roshoxing", Cui Hong's "Sihao Song", Chang Jing's "Fufeng Song", Zu Shubian's "Thousand-mile thinking", Wang Rong's "Dadinv", Xiao Zong's "Listening to Zhong Ming" and "Sorrowful and Falling Leaves", 8 songs of Wen Zisheng's "Dun Huang", "Jiang Nan Qu", "Anding Hou Qu", "Knot Socks", "White Nose" and "Xiangguo Qinghewang Elegy". Sun Kaidi, Yu Guanying, Xiao Difei, Luo Genze, Wang Yunxi, Liu Dajie, Cao Daoheng and other experts verified that there was "The Song of Mulan".

\section{CREATION AND EXISTENCE OF YUEFU LYRIC POETRY IN WEST WEI DYNASTY AND NORTHERN ZHOU DYNASTY}

The Yuefu poems of Western Wei Dynasty and Northern Zhou Dynasty were included in the "Yuefu Poetry Collection". The songs in the "Country Temple Song" include 12 songs from "Siyuan Qiuge", 4 songs from "Sifangze", 12 songs from "Siwudi Song", 12 songs from "Zongmiao Song" and 2 songs from "Dahe Song". There are 42 songs in total. All are believed to do it. "Yan shooting Song" has 24 songs in "Five Tunes" and is also made by $\mathrm{Yu}$ Xin.

"Xianghe Song" includes Xianghe, aria, and four-string, Pingdiao, Qingdiao, Sediao, and Chu-song. In Hengchui Ciqu, there are Hanhengqu and "Qingshang qu." There is a succession of "qin lyrics". The verses are from the north, the hot line, the off-court youth fielding, the Ranger, the Lingyuntai, the ancient music, the Goguryeo, Mei Niang, Dreamland $\mathrm{Ci}$, widow-in-law. These works were mainly written by $\mathrm{Yu}$ Xin and Wang Bao. They were mostly written in the Southern Dynasties. After the author's examination, his works were made in the Western Wei, Northern Zhou dynasties.

Yuxin's "Yan Ge Xing" mainly describes the North scenery. It is authentic. "First Army" 1 mainly describes war scenes and is truly sensible. There are "Meiniang" and 10 songs of "Dreamland Ci". There are no similar works in the South dynasty. And "Wu" six words. And the words are more brilliant. After entering the North, they made "Yan Shooting Song" with six words. And they also would make poems with Zhao Wang et al. Zhou Chong in northern area would also make a lot of Hong Shi Jiao.

The second poem of Wang Xi's "Joining the Army" describes the true sensibility. And the king of the North Zhou has the same title. "Expedition People" is the first four sentences of the second episode of "Joining the Army". Only the first word of the second sentence is different. "Yinma Great Wall Cave" describes the battlefield conquest and the bitter cold of the North. There is a true experience of the North. It is the same as the North Zhou. In "Qiangshang nanweiqu", there is a sentence that white jade ask for the good price, and the pearl is difficult to make the investment. The wind has the history of years. It seems to describe individual thinking. "Exit" is a real description. It is due to the actual sentiment of the scenery in the North. In "Ling Yuntai", "Let's read Xiling Dance, it wouldn't be in Ye city". "Xiling" seems to refer to Liangdu in Jiangling. "Yecheng" is the capital of the Northern Qi Dynasty. It seems to be in the Northern Zhou Dynasty. "Goguryeo" uses six words, takes the name of the foreign national kingdom into the subject, the contents of the sadness of life. The sentence patterns and topics are rare in the Southern Dynasties. And there is title in the Northern Wei Dynasty.

Li Delin and Xin Deyuan of Northern Qi, the Northern Zhou Dynasty, the Sui Dynasty, and Xiao Cen of the literary genius between Zhou and Sui dynasty also had Yuefu lyric poetry. Li Delin's "Meeting on the Narrow Road" is not paralleled. The language is shallow and simple. It is made in the Northern Qi Dynasty and the Sui Dynasty. In Xin 
Deyuan's "Cheng Lian", "the solider would go far away, and they can't be back." "They only communicate through the letters, and the customers' cloth is thin." It is similar to the confederacy of the confession, making melody music from the status quo. From Qi dynasty into Zhou dynasty, they would leave home. With all kinds of discomfort, the political situation is dangerous and dreadful. Xiao Cen's "Zhaoge Xing" is simple, and the music could be seen as the same title of Yuefu lyric poetry of North and South Dynasties.

In addition, the local author Zhao Yuwen of the North Zhou Dynasty enrolled "Joining the Army", 2 songs from Xu Qian's "Short Songs", and "Yinma Great Wall Caves".

\section{CREATION AND EXISTENCE OF YUEFU LYRIC POETRY IN EASTERN WEI DYNASTY AND NORTHERN QI DYNASTY}

The Yuefu lyric poetry of the Eastern Wei and Northern Qi Dynasty are also mainly found in the "Yuefu Poetry Collection". "Countryside Songs" include 13 songs in "Southern Outskirts", 8 songs in "Northern Outskirts", 5 songs in "Five Rural Songs", 11 songs in "Mingtang Music", and 18 songs in "Music of Enjoying the Countryside". There are 55 songs in total. "Yan Shooting Song" has "Yuanhui Daxiang Song", a total of 10. "Dance music song" has 4 songs of "Ya dance" and "Wenwu dance song".

"Xianghe Song" includes Xianghe, aria, four-string, flattone, clear-faced, melody, and Chu-tune. "Guichui" has some thoughts. "Qingshang rhyme" has Jiangnan Lane. "Qinqu" has piliyin, Yilancao, Feilongyin. "Music Songs" include Qisexing, ascension, immortality, dongfei bolao song, Hibiscus Flower, Yellow River, Yongshile, Sigongzi, Hequ tour, road trips, and banquets in the south of the city. There are chanting songs in the "Songs".

The native writer of Northern Qi Dynasty, Wei has 1 song of "Zhaogexing", Yongshile, 2 songs of Beauty, "Xiase Song", Gaoang's "Road trips", Zuting's "Elegy", Pei Rangzhi's "thinking", Xing Shao's "Sigongzi", Hu Lvjin's "Chi Lege", and Yin Yingtong's "Cai Lianqu".

Xun Zhong, entering Northern Qi Dynasty from Eastern Wei dynasty, has "Tongquetai". It's lonely. It describes the author's mourning for the former dynasty.

After the start of the Northern Qi Dynasty, Xiao Que, Xiao Gu, Lu Sidao, Xue Daoheng, and Xin Deyuan in the Sui Dynasty have the Yuefu lyric poetry. Xiao Que's "Flying Dragon cited" and "Jihuanghe" were eloquent and active in content. In "Northern Qi-Xiao Que", he had got much attention. And his main works are created in the Northern Qi Dynasty. The style is similar to that of the Southern Dynasties. However, he didn't achieve his own goals. Xiao $\mathrm{Gu}$ has the song of "field and vertin". And the scholars believed that Lu Qinli's "the poems of Qin, Han, Wei, Jin and Northern and Southern Dynasties" were created in the Northern Qi Dynasty. It is Lu Sidao's "Sunrise in the South East". There are many same titles in the Southern Dynasties. However, there is no same title in the Northern Dynasty. In Wei dynasty, it has the same title of "Zhaoge Xing". "Cailian $\mathrm{Qu}$ " is active in content. Emperor Jianwen of Liang dynasty, Emperor Yuan, Liu Xiaowei, Zhu Chao, Shen Junxi, and Wu
Jun made the same title. They all had five words and eight sentences or more. In "Beauty", Northern Qi Dynasty and the Wei Dynasty establish the capital at Yecheng. And it has a similar title in Wei dynasty. In "Hequyou", "it has the trend in Yecheng." In "south city", "the song was spread frequently." It was made in Northern Qi dynasty. Xue Daoheng's "Yuzhang Xing" is positive in style. According to "North History-Xue Daoheng Biography", he worked in Wenlinguan in the Northern Qi Dynasty. In Zhou dynasty, he abandoned the official hometown. And then, he took the small officials. And he would fight with the army. He was dead in the period of emperor Yang. It wouldn't be made in Zhou and Sui dynasties. Jianwen emperor, prince of Wuling, Shen Yue and others had the same title. We could find it in Zhou and Yan dynasties. Xin Deyuan' made "Short Song". Zhang Shuai and others of the Southern Dynasties have similar works. According to the history, he worked in Wenlinguan in the Northern Qi Dynasty and was highly valued. After entering the Zhou Dynasty, his didn't take any officials. Therefore, it should be done in the Northern Qi Dynasty. "Piliyin", "White Horse", "Dongfei Bolau", and "Hibiscus" are positive in the contents. According to Xie Xiyi's "Qinlun", the author was active in the officials at that time. It is believed that it is made in Northern Qi dynasty.

\section{CONCLUSION}

In short, the Xianbei regimes actively participated in the history and promoted the establishment and continuation of the Xianbei dominant position. At the same time, it also enabled the Northern Dynasty's Yuefu poetry to have the stigma of the Xianbei ethnic group to a certain extent. During the entire period of the Northern and Southern Dynasties, there are at least 254 songs of Yuefu poetry on the Xianbei regime. These works were diverse in subject and varied in content. They were mainly composed of five words, supplemented by four, six, and seven words. The style was clear, desolated, and delicate. Each Yuefu would has inherited the experience of the former. And there are many common features of the same title in Yuefu lyric poetry. However, they can create their own works according to their own circumstances, reflecting the characteristics of the times and their own unique style.

\section{REFERENCES}

[1] (Tang) Fang Xuanling. Jin Shu [M]. Beijing: Zhonghua Book Company，1974：2537.（唐）房玄龄.晋书[M]. 北京:中华书 局, 1974:2537.

[2] Cao Daoheng, Liu Yuejin. The Chronicle of Literature of the Southern and Northern Dynasties[M]. Beijing: People's Literature Publishing House, 2000:4. 曹道衡,刘跃进.南北朝文学编年史[M]. 北京:人民文学出版社,2000:4.

[3] Zhou Jianjiang. Northern Literature History[M]. Beijing: China Social Sciences Press, 1997:55. 周建江. 北朝文学史[M].北京:中国 社会科学出版社, 1997:55.

[4] (Song) Guo Maoqian. Yuefu Poetry Collection [M]. Beijing: Zhonghua Book Company, 1979: 362. (宋) 郭茂倩.乐府诗集[M]. 北京:中华书局, 1979:362.

[5] Lang Ying, Zhala Ga. Studies on the relations between ethnic groups in China (from the pre-Qin dynasty to the Tang and Song dynasties) [M]. Guiyang: Guizhou People's Publishing House, 2005: 189-190. 
郎樱,扎拉嘎.中国各民族文学关系研究（先秦至唐宋卷）[M].贵 阳:贵州人民出版社,2005:189-190.

[6] (post-Jin) Liu Shun et al. Old Tangshu [M]. Beijing: Zhonghua Book Company, 1975: 1071-1072. （后晋）刘眴等.旧唐书[M].北京:中 华书局,1975:1071-1072.

[7] Gao Renxiong. The Narration Theory of Nationality Literature of Northern Dynasties [M]. Beijing: Zhonghua Book Company, 2011:49-50. 高人雄. 北朝民族文学叙论 [M]. 北京: 中华书 局,2011:49-50.

[8] Zeng Zhian. Liang Gujiao's horizontal blows and miscellaneous examinations [A]. Wu Xiangzhou. Yuefu School (third series) [C]. Beijing: Xueyuan Press, 2008:123-125. 曾智安. 梁鼓角横吹曲杂考 [A]. 吴相洲.乐府学 (第 3 辑) [C]. 北京:学苑出版社,2008:123125.

[9] Xiao Difei. The History of Yuefu Literature in Han, Wei and Six Dynasties[M]. Beijing: People's Literature Publishing House, 1984:280. 萧涤非.汉魏六朝乐府文学史[M]. 北京: 人民文学出版 社, 1984:280.

[10] (North Qi) Wei Shou. Wei Shu [M]. Beijing: Zhonghua Book Company, 1974: 2843. (北齐) 魏收. 魏书[M]. 北京: 中华书 局, 1974:2843.

[11] (Japan) Qingshui Kaifu. Literary Essays of Six Dynasties [M]. Chongqing: Chongqing Publishing House, 1989: 348-349. （日）清 水凯夫.六朝文学论文集 $[M]$. 重庆:重庆出版社,1989:348-349. 